UC-NRLF

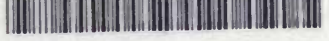
के $271 \quad 325$

THE FNGLISH

\title{
FIOOXER GARDEN
}


3 की S

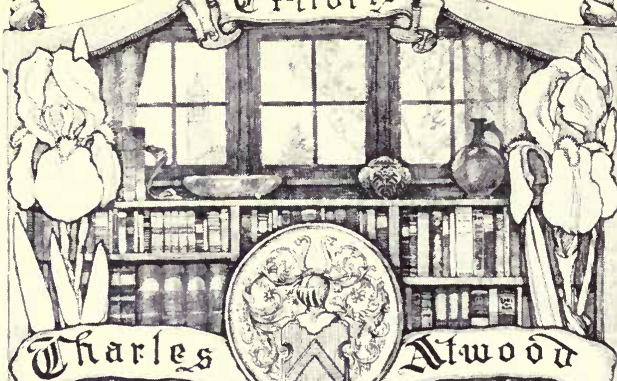
(i)harles

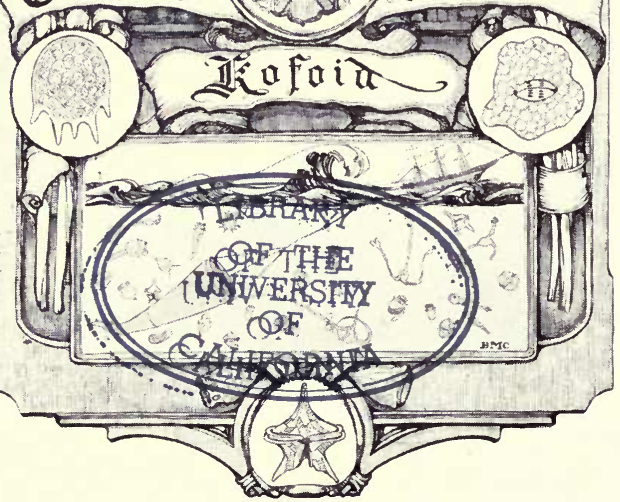

सखक 
fon 
THE

ENGLISH FLOWER GARDEN. 


\section{$-$}

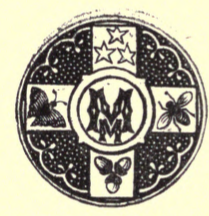




\title{
THE
}

\section{ENGLISH FLOWER GARDEN}

\section{WITH ILLUSTRATIVE NOTES}

\section{HENRY A. BRIGHT}

AUTHOR OF “"A YeAR in A LANCASHIRE GARDEN."

\author{
Ponton: \\ M A CMILLAN AND CO. \\ I $88 \mathrm{I}$.
}

The Right of Translation and Reprodution is Reserved. 
LONDON :

R. Clay, Sons, and Taylor, BREAD STREET HILL. 


\section{S13405 \\ 1385}

\section{P R E F A C E.}

IT is just a year ago since this Essay on "The English Flower Garden" was published in the Quarterly Review.

It was written with a twofold object: to give in the smallest compass an outline history of English gardens, and to show once again what makes the true charm and happiness of a garden. Many-perhaps too partial-friends have urged me to reprint this article. They have reminded me that, when the immediate circulation of any one number of a Review has ceased, its articles are virtually lost and buried, and they assure me that there are readers who may not have already seen, and who would yet care to read, this Essay. I hardly know how this may be, but I do know 
how very much I am indebted to the proprietor of the Quarterly for his great kindness in allowing me the opportunity of this reprint. Should this little book succeed in retaining the friends that A Year in a Lancashive Garden was happy enough to make, it will indeed be fortunate. It has been to me a matter of no little surprise (as, naturally, of pleasure) to find from the generous notices of the Press and from numerous private letters from owners of gardens, to whom I am entirely a stranger, that the views I have expressed as to the necessity of a reform in our gardens are very widely held. So long as a garden is only regarded as a means for displaying masses of gay colouring, half the delight and all the real interest of it are gone. It is only when we learn to make friends of individual plants, and recall their history and associations, that a garden becomes a pleasure for the intellect as well as for the senses. But I do not wish to carry my opinions to any extravagant length. It is Voltaire, I think, who says that "a man may have preferences but 
no exclusions," and I certainly would exclude nothing that is good in the present system. Bedding-out is occasionally very effective and sometimes necessary; and, on the other hand, a garden-such as I saw suggested somewhere the other day-which should contain only flowers known to Chaucer, would be extremely disappointing. However, bedding-out can take very good care of itself, and Chaucerian gardens will not be largely popular. Meanwhile, I sincerely hope that flowering shrubs and hardy herbaceous plants may be far more generally grown and cared for than they are at present.

It has seemed on the whole best to leave this Essay as it was written. I have made a few verbal corrections and inserted one or two short sentences, and that is all. I have, however, added illustrative Notes on points which seemed of some little interest. 


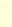




\section{CONTENTS.}

PAGE

Love of Gardening . . . . . . . . . . . . . I

Early English Gardens . . . . . . . . . . . 3

TOPIARIAN WORK . . . . . . . . . . . . 8

Landscape Gardeners . . . . . . . . . . . . I I

Bedding-Out . . . . . . . . . . . . . . . 16

Carpet-Bedding . . . . . . . . . . . . . . . 23

SPRING Gardening. . . . . . . . . . . . . 26

The Semi-Tropical Garden . . . . . . . . . . 27

The Alpine Garden . . . . . . . . . . . . . 29

Fountains . . . . . . . . . . . . . . 3 .

The Wild Garden . . . . . . . . . . . . 32

The Shrubbery. . . . . . . . . . . . 35

Hardy Shrubs . . . . . . . . . . . . . 39

The Walled Garden . . . . . . . . . . . 43

Old Herbals . . . . . . . . . . . . . . 45

Flowers of Winter . . . . . . . . . . . . 47

SPRING FlOWERS . . . . . . . . . . . . . . 49 


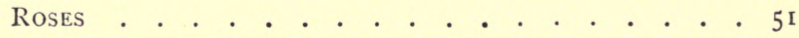

Summer Flowers . • . . . . . . . . . . . 52

Birds and Butterflies . . . . . . . . . . . . 55

EXPLORERS. . . . . . . . . . . . . . 57

Botanists . . . . . . . . . . . . . . 6 ( .

Garden Associations . . . . . . . . . . 65

Flower Painting . . . . . . . . . . . . . 67

Flower Shows . • . . . . . . . . . . . . . 7 I

The Interest of THE Garden . . . . . . . . . 74

\section{NOTES.}

I. The Gardener Bower-Bird . . . . . . . . 78

II. ARS TOPIARIA . . . . . . . . . . . . 82

III. A Poet's Flower-Bed . . . . . . . . . . 86

IV. The Evening Primrose . . . . . . . . . 87

V. The Christmas Rose . . . . . . . . . . 92 


\section{THE}

ENGLISH FLOWER GARDEN. 



\section{THE}

\section{ENGLISH FLOWER GARDEN.}

As spring comes on, the fancy of any man who cares about a garden, "lightly turns to thoughts" of flowers and the gardens where they grow. Never, perhaps, was the art of gardening so popular,-I wish we could say so intelligent,-as at present. The stately homes of England, the villas that line the roads of suburban districts, the cottages clustering round a village green, often even a back yard or window-sill in the heart of some manufacturing town, all testify in their different ways to the desire of having an adornment of flowers. Indeed this desire, as Bacon long ago pointed 
out, in his famous and often-quoted essay, is as old as man himself; or, if any one prefer to trace back the instinct, not to the Garden of Eden, but to the habits of a bird, he may be reminded of the Gardener Bower-bird (Amblyornis inornata) of New Guinea, who, making a bower for the pleasure of his mate, will decorate the front of it with flowers carefully stuck into the sod. ${ }^{x}$

Nothing more strikingly shows the interest that is now taken in gardening than the number of books that are published on the subject. Besides those that deal less with the craft of the gardener than with the flowers themselves, we have Manuals of gardening, with their annual and monthly calendars of gardening operations, their practical advice and technical knowledge. Then there are the almost countless catalogues of the nurserymen and seedsmen, which often add excellent, and sometimes coloured, engravings, and always supply much useful information. Moreover, in addition to the gardening articles

I See Note I., on the Gardener Bower-bird. 
that appear in the Field and elsewhere, there are no less than six weekly newspapers, and five monthly periodicals, all devoted to gardening.Lastly, from time to time some publication comes out in parts, as a monograph on some particular species or group of plants, which, with its beautifully-painted illustrations, will one day take its place among other magnificent folios in the botanical libraries of the world.

So much has been written about the old English or Elizabethan garden, that I need hardly enter into great detail on the subject. Bacon has told us what his ideal garden wasthe outside lawn, the enclosed garden, and the wilderness. Of course few gardens can ever have approached the perfection of which he dreams, but his general type was the type of the garden of his day. He does not approve of "the making of knots or figures with divers coloured earths" near the house; but in the garden proper, which is enclosed by hedges with green alleys running past them, he will allow of "variety of device." Each month is to 
have its own flowers, and he values flowers, as Milton seems to have done, more for fragrance than for colour. And the variety of flowers of the old garden was, even in comparatively small places, far greater than we might at first suppose. Thomas Tusser, who was then a Suffolk farmer, published his Points of Husbandry in 1557 , and he gives a long list of the plants he grew for the kitchen, for salads, for physic, and of flowers for "windows and pots." The New Shakespeare Society, too, has lately been reprinting Harrison's Description of England, first printed in 1577 , and he, in a chapter on gardening, describes his own "little plot, void of all cost in keeping," as having, "in the varietie of simples," "verie neere three hundred of one sort and other contained therein, no one of them being common or usually to be had."

Two of the most celebrated gardens of those days were Nonsuch and Cobham. Nonsuch seems to have had a number of statues, and a wonderful fountain, with Diana and Actæon; and its lilac-trees are particularly mentioned. 
Of Cobham, in Kent, then belonging to Lord Cobham, but now to Lord Darnley, Holinshed says, "No varietie of strange flowers and trees do want, which praise or price maie obtaine from the furthest part of Europe or from other strange countries, whereby it is not inferior to the Garden of Semiramis." A little later, Lord Fairfax's garden at Nun-Appleton was glorified by Andrew Marvell. It was built, as was supposed to be appropriate for a soldier's garden, in the form of a fort with five bastions, and

\author{
" the flowers as on parade \\ Under their colours stand displayed, \\ Each regiment in order grows, \\ That of the tulip, pink, and rose."
}

Later on still (in I685) Sir William Temple, in his celebrated essay, described the gardens in his day as not often exceeding six or eight acres, enclosed by walls, and "laid out in a manner wholly for advantage of fruits, flowers, and the product of kitchen gardens." He goes on to say, that

"In every garden four things are necessary to be provided for, flowers, fruit, shade and water, and whoever lays out a garden 
without all these must not pretend to any perfection. It ought to lie to the best parts of the house, so as to be but like one of the rooms out of which you step into another. The part of your garden next your house (besides the walls that go round it) should be a parterre for flowers, and grass-plots bordered with flowers; or if, according to the newest mode, it be cast all into grass-plots and gravel walks, the dryness of these should be relieved with fountains, and the plainness of those with statues."

He then quotes the garden at Moor Park, made by the Countess of Bedford, as "the perfectest figure of a garden I ever saw." He says, "the length of the house, where the best rooms or of most use or pleasure are, lies upon the breadth of the garden:" the "great parlour" opens upon a broad terrace walk, and then three flights of steps descend to a very large parterre, with its standard laurels, its fountains, and its statues. This garden must obviously have been a garden of an architectural rather than of a horticultural character, and was not at all the ordinary garden of the ordinary country house. But the garden, which we properly associate with those described by the poets of the sixteenth and seventeenth centuries, was the garden "enclosed by walls," within which were flower-beds and herb and 
kitchen gardens, divided by flowering shrubs, and green walks, and verdant alleys. It was in such a garden that Spenser's butterfly met its untimely end, and such were

\footnotetext{
" The gardens of Adonis, fraught With pleasures manifold."
}

It was in the "pleached bower" of such a garden, where the ripe honeysuckles obscured the sun, that Shakespeare's Beatrice was to hide. Of such a garden Andrew Marvell was thinking when he described the lilies and roses, on which Sylvio's fawn was wont to feed. In these old gardens Cowley wrote his essays; and Herrick gathered the fancies of a poet, or the warnings of a moralist, with his early violets and fading daffodils.

And so, with but few changes, these Elizabethan gardens grew on from year to year, till a certain modification occurred when William III. introduced a taste for whatever was characteristic of Holland: statues were fewer, and hedges of box or yew, clipped into fantastic shapes, became all 
the fashion. These clipped hedges, indeed, were no new invention, as Sir Walter Scott appears to have thought, for Bacon had denounced them. He did "not like images cut out in juniper or other garden stuff, they be for children." Earlier still, Leland, in his Itinerary, speaks of the Castle of Wrexhill, and says that outside "the mote" were orchards, and "in the orchards were mountes opere topiario." x

But the most famous specimen of Topiarian work in England is probably that at Levens Hall in Westmoreland. It was the work of Beaumont, a well-known gardener of his day, and dates from I70I, the last year of William III.'s reign. Colonel Graham was at that time owner of Levens, and some curious letters from his steward still exist, describing the laying-out of the grounds and the planting of the yews, of which one group was clipped into the shape of Queen Elizabeth with her maids of honour.

Long rows of trees, moreover, were now formed on the several sides of great houses, and at x See Note IJ., on Ars Topiaria. 
Cobham (the varied fortune of whose garden is singularly instructive) a semicircle of trees was planted near the west front, from which radiated five avenues. But the Dutch fashions and the Topiarian work and the long avenues were to be of no long duration. It is more than probable that political feeling, as well as mere fashion, may have had something to do with the change in many cases; but, however this may be, those who set themselves up as men of taste began to find fault with the existing style. Pope was among the first to discover that there was a monotony when grove nodded to grove and each alley had its brother, and he insisted that nature must "never be forgot," and that one must "consult the genius of the place in all." So he set to work to consult the genius of his own villa at Twickenham, and this genius certainly prevented anything monotonous. He had flowerbeds, and slopes, and mounds, and vistas, and a cypress-grove, and a shell-temple, and an orangery, and a bowling-green, and, above all, a wonderful grotto, "finished with shells, and 
interspersed with pieces of looking-glass in angular forms."

And it was about this time that Batty Langley, also of Twickenham, wrote his New Principles of Gardening, or the Laying-out and Planting Parterres, Groves, Wildernesses, Labyrinths, Avemues, Parks, Ecc., after a more Grand and Rural manner than has been done before. This "grand and rural manner" expresses pretty clearly the confusion we find all through his book. $\mathrm{He}$ must have known Pope's villa, and probably the poet himself, and it is evident that he too intended to consult nature and the "genius" of a place. He says there is not "anything more shocking than a stiff regular garden, where, after we have seen one quarter thereof, the very same is repeated in all the remaining parts, so that we are tired, instead of being further entertained with something new as expected." $\mathrm{He}$ thinks "our gardens much the worst of any in the world, some few excepted," and is severe on the late Mr. London and Mr. Wise for having laid out gardens for the nobility "in a regular, stiff, 
and stuft-up manner," with crowded evergreens and "trifling flower-knots." But the compliments which he pays to nature are, after all, not much more than lip-homage. His principles seem very right, but his designs, of which we have very many, show that the "grand" had quite got the better of the "rural." Even the design of "a rural garden after the new manner" consists of "a fine large plain parterre, environed with an easy, agreeable slope," and "adorned with Apollo, Minerva, and Pallas (sic), the Seven Liberal Arts, Mercury, and Pytho;" then there is an octagon basin, with Neptune, and avenues and canals and more statues, and "we can never know when we have seen the whole."

And now the period of the so-called "landscape gardeners" began, though in reality their business was rather with the grounds than with. the garden proper.

Of these Kent was the first of eminence. Their idea was to destroy all the old-fashioned formalities, at the sacrifice of a certain stateliness which the style possessed, and to bring the scenery 
of an English park up to the house itself. But they were constantly haunted and harassed by the word "picturesque." Was Nature more picturesque when closely followed or carefully improved? Was it the duty of the landscape gardener to arrange his clumps and belts of trees in the way in which they would look best in a picture? This was evidently Kent's idea, and Daines Barrington, speaking of him, says it was reserved for him "to realize these beautiful descriptions [in the Faery Queen], for which he was peculiarly adapted by being a painter, as the true test of perfection in a modern garden is that a landscape painter would choose it as a composition." Kent's great work seems to have been the carrying out of the alterations at Stowe, on which Bridgeman had been originally employed, and much of the beauty of those famous grounds-which, however, were at least as artificial as natural-was owing to his taste. The two peculiarities now generally associated with his name are the planting of dead trees to look picturesque, and the constant use of $\mathrm{Ha}$-ha's 
(or sunk fences), which he is often said to have originated, though, as matter of fact, Batty Langley also (and I think previously) advocates their adoption. " "Capability Brown" was perhaps the next most noted landscape gardener. His idea was always to improve nature, and he was particularly strong in artificial lakes and canals, with rather formal clumps of trees. He had many disciples, and it seemed as if half the fine places in England were to be reformed on the new principles. But two formidable critics came into the field, Knight and Price. Their plan was to leave Nature as much as possible to herself, to let the stream wind about as a stream should, instead of being dammed into a canal, and to allow trees to grow as they liked. Price's famous Essay on the Picturesque is still full of interest, and shows good sense in the exceptions he allows to his general rule, as, for instance, where

I Horace Walpole says that Bridgeman invented the sunk fence, " and the common people called them 'Ha ! ha's !' to express their surprise at finding a sudden and unperceived check to their walks." He adds that Kent "leaped the fence, and saw that all Nature was a garden." 
he admits "architectural ornaments" in the garden round the house. He speaks, too, with regret of having once destroyed a beautiful old garden, "sacrificed to undulations of ground only." But he certainly seems to carry his general rule to very considerable length. He thinks that "many of the circumstances that give variety and spirit to a wild place might successfully be imitated in a dressed place;" and although he cannot advocate modelling a carriage-drive after a cart-rut, or having waterdocks or thistles before one's door, he still thinks the cart-rut and the thistles might furnish useful hints. In another chapter he discusses "the connection between picturesqueness and deformity," and explains how large heaps of stones or mould may at first be considered as deformities and afterwards appear picturesque. It is impossible not to be reminded of Mrs. Rafferty's description of her garden in Miss Edgeworth's Absentee: "'Yes,' she said, 'she hated everything straight; it was so formal and unpicturesque. Uniformity and conformity; she 
observed, 'had their day, but now, thank the stars of the present day, irregularity and deformity bear the bell and have the majority.'"

Another novelist, Miss Austen, in her Mansfield Park, preserves the name of Repton, who was the last of the noted landscape gardeners of the last century: "Repton, or anybody of that sort," says a certain Mr. Rushworth, "would certainly have the avenue at Sotherton down; the avenue that leads from the west front to the top of the hill, you know." And this is just what Repton would have done. $\mathrm{He}$ was for ever cutting down avenues, and out of the five beautiful lime avenues at Cobham, which must have given such a stately appearance to the place, no less that four fell victims to his axe. The idea was of course that avenues prevented the ground from being picturesque and natural, and Mason, in his English Garden, urges "the cruel task, yet needful," of breaking " th' obdurate line" of trees, though

" A chosen few, -and yet, alas! but fewOf these, the old protectors of the plain, May yet be spared." 
The next marked development in gardening refers more particularly to the flower-garden itself. It was between the years 1835 and 1840 that the mode which we call "bedding-out" began to came into general fashion. John Caie, who was gardener to the Duke of Bedford, and afterwards at Inverary Castle, is often said to have originated the system; but Mr. Frost, writing from Dropmore to the editor of the Gardener's Chronicle, says :

"I helped to fill the beds here in the spring of 1823 , long before Mr. Caie had charge of the Campden Hill gardens. It was Lady Grenville who began the hedding system in the first place, but she quite abhorred both ribbon and carpet bedding. The dowager Duchess of Bedford used to visit the grounds here, and much admired the garden, and when she went to Campden Hill to live she sent Mr. Caie here to see the place, and very probably to take. notes of what he saw."

It would thus appear that to Lady Grenville in her Dropmore gardens the credit of being the first to bed-out may fairly belong. But some fifteen years passed before the system was generally adopted. It then grew rapidly in favour, and before long it was clear that the 
whole character of the English garden would be changed. One of the first plants to be beddedout extensively was the "Tom Thumb" pelargonium, or geranium as it was then more commonly called; it was a dwarf scarlet, and was considered to be of great beauty till the better varieties were introduced. Then followed verbeneas, calceolarias, and other flowers, which could be kept as cuttings through the winter, and then be planted out when summer weather made it safe to do so. And there were many advantages in bedding-out. In large public gardens, where a glow of colour only was wanted, where no one stopped to look at any particular plant, and where a certain uniformity of growth was essential, it answered extremely well. In gardens which are, as it were, the approaches of great houses, and which seem laid out rather by the architect than the gardener, the beddingout system was both convenient in itself and striking in its effect. Nothing for instance, in its way, can be more beautiful than to look down from the long gallery at Crewe Hall 
upon the formal garden with its curves of variegated gravel and its thick box edging, its broad terraced walks and flights of steps, guarded by quaintly-carved balustrades and strange heraldic monsters. But it hardly strikes one as a garden ; it is rather an appendage to the house itself, adding to its stateliness, and recalling, by its prevailing colours of buff and blue, the old traditions of the family.

But what is all very well for public parks and very important mansions is out of place in smaller country houses, and becomes absurd in small villa gardens. However, the fashion had seized hold of gardeners and masters both, and every one must have what was called an Italian garden. But to make their Italian garden they must do one of two things. They must either root up the old herbaceous plants, which year after year had blossomed and scented the air in the old walled garden; or they must take a piece of their lawn, and, cutting it up into segments, then plant out their nurslings of the greenhouse. It so chanced, moreover, that a 
few years after the new fashion came in, the duty on glass was taken off, and greenhouses, which had once been a luxury, now became asupposed necessary of life. Hence, bedding-out, instead of being an expensive form of gardening, became a singularly easy and not a very costly method of having a certain show of bright and effective colouring. But this colouring was all. In the old walled garden, instead of the plants, which so long had had their home there, each of which knew its season and claimed welcome as an old friend, there were bare beds till June, and then, when the summer was hottest, a glare of the hottest, brightest, colours. But the walled garden was better than the newly-cut circles on the lawn. In the garden there would at least be the shade of one of the garden walls. In the outside Italian garden, where, with the smooth old turf, trees had been cut away, there would be no shade whatever. Nobody would really care to walk there, and probably no onc would be allowed to gather flowers, for fear of spoiling the symmetry of the beds. Nor can 
any one feel the slightest interest about the hundred little pelargoniums in one bed, or the fifty calceolarias in the next. Each plant is exactly like its neighbour. All individuality has gone, and it is impossible to forget that some four months is the limit of their short lives, and that the next year a new "crop" of pelargoniums and calceolarias, equally without interest or character, will appear in their place. Then too the bedded-out plants are plants with no associations as regards the past. No poet ever sang their beauty, and no legend tells the origin of their birth. Again, they are almost entirely destitute of scent, and to our forefathers at least the scent of flowers was their chief attraction. Often too it is questionable whether a number of small beds cut out of the green turf really looks well; in nine cases out of ten it has a make-shift appearance; flowers were wanted, and the lawn has been sacrificed.

"Nothing," says Bacon, “is more pleasant to the eye than green grass nicely shorn,"-a sentiment which Mason, in that somewhat tire- 
some poem of his from which I have already quoted, has sense enough to approve-

"For green is to the eye, what to the ear Is harmony, or to the smell the rose."

But green lawns all over England were being destroyed. The flower-borders, where there had been no walled garden, had hitherto generally followed the line of the shrubberies and plantations, and the windings of garden walks; but these and the flowers that grew there were now neglected.

Still worse was the effect on the smaller villa-gardens. They had had their flowers on the sunny side of the garden wall, their pleasant bit of lawn with specimen trees, their fence of scented shrubs. The trees were destroyed, the lawn was cut up; and all for the sake of red and yellow patches during four summer months. Even the cottagers in many places seem to have forgotten the old English flowers, such as grew in Perdita's garden, the "hot lavender," the marygold, the crown-imperial and the lily, and have taken to slips of pelargonium and the like. 
Nor even yet had the abuse of the beddingout system done its worst. There were still, as we have said, in many gardens, strips of border which, not being in the form of rounded beds, were allowed, half under protest as it were, to harbour some of the old flowers. Unfortunately for them, ribbon borders were invented, and the last sanctuary of herbaceous plants was often ruthlessly destroyed. Pelargoniums again, and calceolarias, with lobelias in front, and darkleaved perillas in the background, made up the new ribbon border. It was no doubt effective enough in its way, but we have now seen it almost everywhere, and for the last fifteen years at least. Of course there are happy variations of it in great places, and where the gardener is a man of taste and ability; but it sometimes appears to us that such gardeners must be very rare exceptions. Such a ribbon border as I have described, and extremely badly grown moreover, is, or was a year or two ago, supposed to be the appropriate adornment of Shakespeare's garden at New Place in Stratford. 
A further modification in the round beds has been introduced still more recently. It is the bedding-out of zonal pelargoniums, of echeverias, and of other plants, whose beauty lies in the foliage rather than the blossom. No doubt they give softer tints to the general effect, but they are a poor substitute for the varied beauty of an old garden. It may be difficult to find interest in the ordinary "bedding-out stuff," but they are poetry itself compared to plants which chicfly remind one of the last days of the garden of "the Sensitive Plant," when, instead of all odorous flowers, there were only growths

“ Whose coarse leaves were splashed with many a speck Like the water-snake's belly and the toad's back."

And this latest fancy is itself falling into the further degradation of carpet-bedding. That a carpet should imitate a flower-bed is one thing; years ago in Casa Guidi Windowes, Mrs. Browning wrote of some carpets, where

$$
\text { " your foot }
$$

Dips deep in velvet roses." 
This may be well enough; but who wants flower-beds to look like carpets? They may strike you at first as being ingenious, and even pretty, but the feeling is at once followed by a sense of their essential debasement as regards gardening. No flower is permitted, and the glorification of stonecrops and houseleeks is the chief result. But indeed the geometrical figures of the carpet-bedding are not the worst. The gardeners are now trying their skill in designs on their carpet-beds, and names, mottoes, coats of arms, and other frivolities, are becoming common. The most stupid follies of the Topiarian age were graceful and sensible compared to this. It is less childish to trim a yew-tree into a peacock than to arrange your sedums and alternantheras to look like animals on a badly-woven carpet. Nor has the absurdity even the merit of being original. It is really an old French invention, and about the time of Henry IV. the gardens at Fontainebleau and Chantilly were known for their quaint devices in fowers, their ships, armorial bearings, and 
cyphers interlaced. The whole matter has been well summed up by Sir Joseph Hooker, who writes :

" It is indeed astonishing that the asters, helianthus, rudbeckias, silphiums, and numberless other fine North American plants, all so easily grown and so handsome, should be entirely neglected in English gardens, and this in favour of carpets, hearthrugs, and ribbons, forming patterns of violent colours, which, though admired for being the fashion on the lawn and borders of our gardens and grounds, would not be tolerated on the floor of a drawing-room or boudoir." I

Well, as we can do nothing worse in this direction, we may at last hope for a reaction, in which a new school, with some regard to nature, but without the extravagance of the old "picturesque" gardeners, may bring us back to good taste and common sense.

It is of course absolutely impossible to form even an estimate of the number of bedding-out plants used in our gardens during a single season, to be discarded when the season ends. It must be something enormous. One single florist in the neighbourhood of London sends to market annually more than 80,000 plants of one description

I See Note III., on a Poet's Flower-bed. 
of pelargonium alone. It is calculated that the bedding-out of a single good-sized garden will take at least 100,000 plants to make it effective.

But now, leaving the question of summer bedding-out, we are glad to note signs of real advance in other directions. It is something that within the last ten or fifteen years our gardeners should have discovered that bare earth, all spring, is not particularly beautiful, and should have taken to what is called Spring gardening. All flowers are welcome in spring, and even masses of double daisies are acceptable. But indeed in all the most elaborate bedding-out of summer, there is nothing that can give greater pleasure for colouring than a blue lake of Myosotis dissitiflora, or of autumn-sown Nemophila insignis. Then again, owing to our more rapid and easy intercourse with Holland and Belgium, tulips and hyacinths, which, however, were always in favour, are more used than they were some years ago. The quantities sent over by the gardeners of the Low Countries must be very great. Not 
only do the choicer bulbs go to our own nurserymen, but they are now sent direct to many private gardens; while large auction sales in London, Liverpool, and elsewhere, clear off the inferior roots or those exported by the less wellknown growers. Mr. Burbidge tells us that the value of the flower-roots sent from Holland a year or two ago was nearly $60,000 l$, and one English grower imports annually 160,000 tulip bulbs. A certain proportion of these will be required for forcing purposes for the house and the conservatory, but many more will be used in the open garden. A bed of well-grown tulips is certainly a very beautiful object, and there are some at least who believe in the rich fragrance of the tulip, which a living poet says "might be the very perfume of the sun."

Besides the spring garden, there is in some places the Semi-tropical garden, and in others the Alpine garden. No one has done more than has Mr. W. Robinson ${ }^{x}$ to call up an interest in

I In Gleanings from French Gardens, and Alpine Flowers for English Cardens. 
the broad-foliaged plants which are the chief ornament in the gardens of Paris, and in the delicate tufts of flowers which nestle in the crevices of our rockeries. But there is much still to be done. It is, after all, only occasionally that either Semi-tropical or Alpine gardening is to be seen in any perfection. For the former, Battersea and Victoria Parks are extremely good, and for the latter the Messrs. Backhouse's nursery, near "York, has a deserved reputation. Many very handsome semi-tropical plants are all but hardy, and require at most only a protection during the winter months. The canna was known to Gerard and to Cowley, and needs no more care than a dahlia. The Pampas grass and Arundo conspicua are perfectly hardy. The Arundinaria falcata is rather more tender, but unless it flowers, when, like the American aloe, it will die, it will generally spring up from the root, even when its long canes themselves are cut by the frost. The aralia, ricinus, and others, are no doubt safer 'for being housed during the winter, and then plunged, either as centres for 
flower-beds, or as separate shrubs in the outside garden. Nothing gives greater character to any garden than the occasional introduction of plants like these. They are now indeed all the more needed since the old plan of having orangeries has so nearly disappeared. And yet how well worth the trouble-the very little trouble-that it cost, the orangery always was. Nothing could be more stately than a broad walk, along the sides of which were ranged the orange-trees, each in its huge tub, and each fruit-bearing and flowering together. And with the orange-trees would be the white-blossoming myrtles and the Clethra arboreu, with its scented sprays, like lily-of-thevalley.

As regards the Alpine garden, the first thing to be remembered is, that the rockwork on which it is to be formed should look as natural as possible. Nothing can be more hideous than the usua varieties of suburban rockeries, where the intention seems to be to make everything ds unnatural and distorted as can well be imagined How well one knows the jagged fragments of 
red sandstone standing on end, or the blocks of various formations heaped up together, with bits of green glass, coarse coral, and big shells stuck in at different corners, and with cement between to keep all in place. ${ }^{x}$ The rocks used should, if possible, be the rocks of the country; they should appear to crop up from the soil; and they should be so laid that plants should really be able to grow in their fissures and interstices. Scarcely less important is the choice of a site, for if the rock-garden is placed under the drip of trees it is hopeless to expect that any of the more delicate and beautiful Alpine plants can thrive. Most ferns, on the other hand, will of course do better in moist, shady places; so that it is impossible successfully to combine the Alpine garden and the fernery, as is very often attempted. Let the Alpine plants have sun and light, and give the ferns the cool shade in which they are most at home. Aquilegias and a few

${ }^{I}$ I have just seen the following hopeful advertisement:

"Rockery Ornaments. - To be sold, 500 barrels of Conch Shells, in lots of one or more barrels, at extremely low prices. Apply to - , \&c. \&c. 
other woodland flowers may be planted in among the osmunda, the hart's-tongue, and other hardy ferns; and rare mosses and lichens may be taught to cling to the darker clefts and hollows of the rock, as in one rockery which I know, where the "shining moss" (Schistostega pennata) catches and refracts the sunlight with a metallic lustre like that of the humming-bird's breast.

One of the greatest ornaments to a garden is a fountain, but many fountains are curiously ineffective. A fountain is most beautiful when it leaps high into the air, and you can see it against a background of green foliage. To place a fountain among low flower-beds, and then to substitute small fancy jets, that take the shape of a cup, or trickle over into a basin of gold-fish, or toy with a gilded ball, is to do all that is possible to degrade it. The real charm of a fountain is, when you come upon it in some little grassy glade of the "pleasaunce," where it seems as though it sought, in the strong rush of its waters, to vie with the tall boles of the forest-trees that 
surround it. Such was the fountain in Leigh Hunt's Story of Rimini, which shot up "beneath a shade of darksome pines,"

"And 'twixt their shafts you saw the water bright, Which through the tops glimmered with show'ring light."

Bacon speaks of a "heath or desart" as a part of the garden, and says it is "to be framed as much as may be to a natural wilderness." There are to be no trees there, but thickets of honeysuckle and other trailing plants, and heaps like molehills, set with pinks or periwinkles, or violets, or various "sweet and sightly" flowers, and on some of the heaps little bushes of juniper or rosemary, or other low-growing shrubs, are to be planted. Such a garden would hardly seem to be one of "natural wildness"; but Bacon's theory that there should be a "wild garden" is, with certain modifications, carried out in various places. But to cultivate a wild garden almost involves a paradox. The plants should grow of their own accord, and as their vagrant fancy takes them. The prettiest of all wild gardens is when the bluebells are so thick 
that they seem a reflection of the sky, or the celandine lies in sunny patches on a bank, or the primrose and violet come up here and there at the foot of old forest-trees. Sometimes, too, less common flowers, which have been planted years ago, and have spread as it has pleased them, give an effect of even greater beauty. We remember one large shrubbery all blue with hepaticas, and another golden with the winter aconite. Other plants, such as the anchusa or the Petasites fragrans, may be trusted to take care of themselves, and are well worth some half-wild corner. On the other hand, it is not well to attempt to grow native plants when the conditions of their new life would be unfavourable. It is almost sad to see some bee-orchis, or grass of Parnassus, or mountain auricula, or other rare British plant, transplanted into a shrubbery border. It is far better to leave these "wildings of nature," as Campbell calls them, in their native haunts, and to experience for oneself a new pleasure in finding them growing wild and vigorous on down, or bog, or hilly 
slope. Occasionally a garden flower which has sprung up from some stray seed will add a certain unexpected charm to a walk or grass plot. Such flowers are in a sense weeds no doubt, but "weeds of glorious feature," and there are few who, like Lady Byron-and the story is characteristic-would at once order the gardener to uproot them. One beautiful form of semi-wild garden is where, on some piece of rich peat soil, rhododendrons have been thickly planted. There is a fine example of this at Knowsley, where thousands of large shrubs are growing in the greatest luxuriance, and where, as the slight irregularity of the ground permits, you pass between banks and slopes and hollows, quite purple with the clustered blossoms.

It is of course impossible to lay down any code of rules which would be equally applicable to every garden. As I have already said, there will always be a certain amount of beddingout necessary, especially for the architectural gardens that surround a stately house; but we may hope that in all bedding-out more attention 
will be given than at present to the proper harmony of colours. It really would sometimes appear that half our English gardeners must be colour-blind. The gaudiest and most glaring contrasts pain instead of gratifying the eye, with their crude patches of pink and red and blue and yellow. In France the bedded-out borders have more generally a variety of plants mixed on the same bed, and this certainly tends to soften the general effect.

But both in the outside lawns and shrubberies, and in the walled inner garden, there is much room for improvement. A great principle in laying out the lawns is the old principle of Batty Langley's (a principle which he himself parodied rather than illustrated) of so arranging your grounds that everything cannot be seen at once, and that each turn of the walks excites some fresh interest. The curved lines of a shrubbery, now approaching and now receding, the grass running up into little bays and recesses among deodaras and groups of rhododendrons, specimen trees occasionally breaking a formal 
line, but never dotted about at regular intervals, -these are the features that lend attraction to a lawn. We would allow of no flower-bed whatever except the shrubbery border, though an occasional clump of tritomas, of cannas, or of Pampas grass, may take the place of flowering shrubs, and start up from corners of the grass. Their height and general aspect enables them to form part of the picture. But-one cannot repeat it too often-the expanse of the lawn should be rarely broken except by shrubberies; and that the lawn itself should be carefully kept and free from weeds is of course essential.

One of the most beautiful gardens I ever knew depended almost entirely on the arrangement of its lawns and shrubberies. It had certainly been most carefully and adroitly planned, and it had every advantage in the soft climate of the west of England. The various lawns were divided by thick shrubberies, so that you wandered on from one to the other, and always came on something new. In front of these shrubberies 
was a large margin of flower border, gay with the most effective plants and annuals. At one corner of the lawn a standard Magnolia grandiflora of great size held up its chaliced blossoms; at another a tulip-tree was laden with hundreds of yellow flowers. Here a magnificent Salisburia mocked the foliage of the maiden-hair; and here an old cedar swept the grass with its huge pendent branches. But the main breadth of each lawn was never destroyed, and past them you might see the reaches of a river, now in one aspect, and now in another. Each view was different, and each was a fresh enjoyment and surprise.

A few years ago, and I revisited the place; the "improver" had been at work, and had been good enough to open up the view. Shrubberies had disappeared, and lawns had been thrown together. The pretty peeps among the trees were gone, the long vistas had become open spaces, and you saw at a glance all that there was to be seen. Of course the herbaceous borders, which once contained numberless rare 
and interesting plants, had disappeared, and the lawn in front of the house was cut up into little beds of red pelargoniums, yellow calceolarias, and the rest.

But we have now to speak of the shrubbery. It will depend on its situation whether or not it is backed by forest-trees, but in any case it will have a certain number of evergreens in front. To plant evergreens alone is generally a mistake. Horace Walpole says that he was "not fond of total plantations of evergreens," and he was certainly right. Shrubberies composed entirely of holly, yew, and pinus must inevitably have a solid, heavy appearance, and their use in winter barely compensates for their melancholy monotony during the summer months. They should, wherever it is possible, have deciduous flowering shrubs planted in among them. Nothing can be prettier than to see the dark shades of the evergreens lighted up by the fresh tender green of lilac or laburnum, while, later in the season, the background of evergreen will in its turn give effect to the purple plumes and golden tresses. 
But there is great art in the laying out of shrubberies and the arrangement of the shrubs. There is the time of flowering to be considered, and no less the various colours of the blossoms, while (very occasionally it is true) the tints of the leaves, as they first expand, or are touched by the chills of autumn, and even the prevailing tone of bark and branches, are studied, so that there may be always some happy effect of colouring. But for the most part all this is neglected. There are very few gardeners who pay the attention they should to the shrubbery, and still fewer owners of gardens who care to interfere in the matter. A pinetum has of late years become something of a fashion, and is therefore often a subject of interest, but the shrubbery and the shrubbery border are scarcely regarded. Lilacs and laburnums, scarlet thorns, and rhododendrons are very beautiful; but to confine our flowering shrubs to these implies either want of knowledge or want of taste. There are numbers besides, perfectly hardy, or only requiring some slight protection in the winter, which are comparatively but little known. 
Even many old favourites have been allowed to become unfamiliar. The white and yellow broom, the Ghent azaleas (excepting perhaps the yellow one), the barberry with its bunches of golden blossom and coral fruit, the Buddleia with its glaucous leaves and honeyed balls like tiny oranges, the Gueldres rose covered with its large white tufts of snow, the scarlet ribes with its brisk scent of black currant, are not to be seen as often as they" once were. The Judas-tree (Cercis), whose little clusters of pink pea-blossom come out so early in the year, and the bladder-senna, whose curious paper-like bags of seed, hanging late on in autumn, burst as you press them with a sharp report, are still more rarely to be found. Of later introductions the Weigelia alone seems to hold its own, but the Desfontainea spinosa, looking like a holly, but throwing out scarlet and yellow tubes of blossom, or the diplopappus, with its leaves like a variegated thyme, and its flowers like a minute aster, are hardly ever seen. But there are many more as good as these.

For covering a house the large magnolia is 
perhaps more beautiful than anything. The perfume of its white flowers, though too strong for the house, fills the air for yards round, and comes in stray whiffs through the open window. This magnolia will flourish abundantly in most places, and if it does not, it is probably owing to its roots requiring to be cabined, cribbed, and confined. Other good shrubs for the outside of the house are the ceanothus, the escallonia, and the cydonia or Pyrus japonica, and these two last are well worth growing as independent shrubs. The Pyrus japonica, moreover, when trained as a hedge, and breaking out all along its twisted stems into knots of cherry-coloured blossom, is extremely beautiful.

And in the more favoured nooks of England greenhouse shrubs, such as camellias and cytisus, may be seen to flourish and flower abundantly in the open air. There is a striking example of this as far north as the Anglesea side of the Menai Straits. Thirty years ago Sir John Hay Williams determined to build a house and form a garden on a steep field sloping down to the 
water's edge. The excessive steepness of the ground made it necessary to construct a number of supporting walls to form terraces; and the entire plan was carried out by the owner without any professional assistance. Huge fuchsias, myrtles, the Fabiana imbricata, and other beautiful flowering shrubs grow up against the house, and, sheltered by a terrace-wall, are magnificent camellias and cytisus. I once saw this garden of Rhianva under rather remarkable circumstances. It was the Sunday (March 24, I878) when the ill-fated Eurydice went down. The snow-storm came on, and the snow-flakes fell heavily on the red and white camellias, which were then in great perfection. An hour later, and the sun was again shining, the snow was melting away, and the blossoms appeared from beneath it as fresh as if nothing had occurred.

In front of the shrubbery border should be placed strong-growing hardy plants, which, once planted, will give no further trouble. The monkshood, with its quaint indigo blossoms, the large evening primrose, whose yellow stars come out 
each night all through the summer, ${ }^{1}$ the foxglove, which will sometimes grow eight feet high and bear from two to three hundred flowers upon a single stem, herbaceous phloxes of every variety of red and purple hue, pæonies and irises, and for late autumn the old Michaelmas daisy, are among the most suitable plants for this purpose.

Passing into the walled garden, we shall probably find the northern side taken up with vineries and plant-houses, with which, however, we have nothing to do, except in so far as they supply us with any tender or half-hardy plants for our garden-beds. In front of these houses will be great borders of stocks and mignonette, scenting the air-the mignonette sweetest when the sun is strongest, and the stocks as evening falls. Broad walks and thick hedges of yew, or privet, or the tree-box, divide the flower from the kitchen garden; and where the walks intersect, there may perhaps be an old-fashioned pond with aquatic plants or a fountain; and here let me say that the rarer aquatic plants might be much more grown 'See Note IV., on the Evening Primrose. 
than they are at present, and of all none is more charming than the Aponogeton distachyon, with its little scent-laden boats of blossom. Every available garden wall will be covered with fruit-trees, beautiful in spring time with the pink flowers of peach and nectarine, or the white bloom of pear and cherry. Near the vineries will probably be the flower garden, divided into small beds by narrow gravel walks, and with long strips of garden stretching down along the side of the vegetables or gooseberry bushes, so that even here there will be something of fragrance and of beauty. Even the kitchengarden itself may be so arranged as to keep the more homely kail-yard out of sight. The graceful plumes of asparagus, the broad grey leaves of the globe artichoke, the trailing luxuriance of the gourd, and above all the festoons of scarlet runners (especially when trained along strings fastened to a centre pole so as to form cones or tents) are anything but unsightly; then a corner should be found for a small herb-garden, with little patches of sage and marjoram, and thyme and mint and fennel. There should be rosemary too, and tansy 
for Easter Sunday, and borage to supply a blue flowering. sprig for claret-cup.

When we come to the flower-beds themselves, we have an almost infinite variety of flowers from which to choose for their adornment. In old days, when the tulips were over, there were beds of anemones and ranunculus - and a bed of ranunculus when the sun shines full upon the scarlet petals is a glorious sight. Then came annuals and herbaceous plants. Now, as each year brings something new, and the old plants, if out of fashion, can yet generally be procured, our difficulty is the difficulty of selection.

We have already quoted Harrison's description of his Elizabethan garden, but it is of course in the old English Herbals that we find the fullest account of what was grown, whether for beauty or for use. The most famous of these are the Grete Herbal, by Peter Treveris, published in I 5 I6, and Turner's Herbal, with the date of I568; but better known than either are Gerard's Herbal, of which the first edition appeared in 1597 , and Parkinson's Paradisus Terrestris, published in 
1629, and dedicated to Henrietta Maria. An early chapter in Parkinson is taken up with the various edgings for "knots and trayles," and he says, "the one are living herbes, and the others are dead materials, as leade, boords, bones, tyles, \&c." Among "living herbes" he mentions thrift as having been " most anciently received," lavender, cotton, and slips of juniper or yew; but on the whole he recommends "French or Dutch boxe." His flowers, he divides into English and "outlandish" flowers, and his list is extensive enough for a good garden of to-day. "Of daffodils," he writes, "there are almost a hundred sorts ;" and his list of "tulipas," as he calls them, extends over several pages, and is at least as full as a modern nurseryman's catalogue.

Two hundred and fifty years have passed since this was written, and innumerable new varieties and species have since been introduced. To name no others, we have the annuals of California and the flowering shrubs of Japan, the heliotrope of Peru, the fuchsia of Chili, and the dahlia of Mexico. But the illustrated pages of Curtis, of 
Sweet, and of Loudon, will help us in our choice of flowers, whether annuals or herbaceous plants. It is impossible to do more than recall the names of some of the oldest favourites: and first among the flowers of the year is the Christmas rose. "I saw," quaintly says old Sir Thomas Browne's son, writing in 1664 , "I saw black hellebore in flower which is white;" and certainly clusters of the large Christmas rose, especially when the slight protection of a bell-glass has been given to them, are hardly less beautiful than the Eucharis itself. ${ }^{1}$ Then come the snowdrops, which should be planted not only on the border, but on some bit of grass, where they may remain undisturbed till the leaves have died away. There is a delightful passage in Forbes Watson's Flowers and Gardens (and Ruskin himself has hardly entered into the secret life of plants more sympathetically), in which, speaking of the first snowdrop of the year, he says :

"In this solitary coming forth, which is far more beautiful when we chance to see it thus amidst the melting snow rather than on the

I See Note V., on the Christmas Rose. 
dark bare earth, the kind little flower, however it may gladden us, seems itself to wear an aspect almost of sorrow. Yet wait another day or two till the clouds have broken and its brave hope is accom. plished, and the solitary one has become a troop, and all down the garden amongst the shrubs the little white bunches are dancing gaily in the breeze. Few flowers undergo such striking change of aspect, so mournful in its early drooping, so gladsome when full blown and dancing in the sunshine."

The crocus comes next, the same crocus that once "brake like fire" at the feet of the three goddesses, whom poor CEnone saw on Ida. This should always be planted, not in thin lines, but in thick clusters, for only then can be seen the wonderful rich depths of colour, which open out to the sun. Tufts of crocus, too, should spring up beneath the branches of deciduous or weeping trees, where the grass is bare in early spring, and when once planted the crocus seems to go on for ever. A writer in the Gardeners' Chronicle says that it is known that a particular patch of white crocus has been in the same spot for above 120 years. It is sometimes said that in course of time the yellow crocus will turn into the coarser and commoner purple crocus. This must be a mere fallacy, but it sometimes appears as if it 
were true. The fact, we take it, is that if the two varieties are placed together the stronger one will gradually get possession of the ground, and supplant the more delicate yellow, just as (as old Waterton used to say) the Hanoverian rats turned out the old brown rat of the country.

Other Spring flowers are far less cultivated in great gardens than in those of less pretension; but no flowers give more pleasure, both from their own beauty, and as being among the first flowers of the year. There are the auricula, or "Basier" (as it is called in Lancashire ballads), with its velvet petals and its powdered leaves; the double primrose, faint smelling of the spring; the hepatica, whose bright little blossoms sparkle like unset gems; the pulmonaria, with blossoms half blue, half red, and milk-stained leaves, for which sacred legends can alone account. Then, above all, are the daffodils, most loved of flowers by the poets, though, once again, in preference to any poet, as less known yet admirable in their way, I will quote a few words from Forbes Watson's book. "The daffodil," he says, "is a plant which 
affords a most beautiful contrast, a cool watery sheet of leaves, with bright warm flowers, yellow and orange, dancing over the leaves, like meteors over a marsh." But we cannot, of course, pass in review all the flowers of the Spring, though we must urge a claim for such old-fashioned plants as Solomon's seal with its palm-like leaves, and the crown-imperial with its circlet of orange-bells.

To beds of anemone, ranunculus, and tulips we have already referred, and we need not again recur to ordinary Spring bedding.

But of course there should always be a bank of violets, over which the soft winds will play, stealing and giving odour; and no less, of course, a bed of lilies of the valley-planted alone, so that their roots may spread to any distance-with their sweet white bells peering here and there from "their pavilion of tender green."

The herbaceous borders of early summer become gayer still, though the individual plants are perhaps less interesting. We have now, with numberless others, the snowflake, the hairy red poppy, the valerian, mulleins of various sorts, the 
early gladiolus, the large flowering lupin, and above all, lilies. The variety of lilies, all beautiful, and nearly all easily grown, is quite remarkable, and we doubt whether (comparatively at least) any flower is more neglected.

Then come roses, and we would strongly recommend that, in addition to the newer "remontant" roses, the old roses and the old way of growing them should not be quite forgotten. Standard roses are all very well, but a rose-bush covered over with blossom is very often much better. "Madame Rothschild" is pre-eminent in beauty, but (if she will tolerate the "odorous" comparison) the old cabbage rose or moss rose has a charm of scent and of association of which their fashionable rival is entirely devoid. The old pink china or monthly rose, which flowers on from early summer to latest autumn, deserves a bed to itself. It should be trained and pegged down, as is so constantly done in Belgium and Holland, and the blue lobelia should be planted in between. A bed of the yellow briar-rose is still more beautiful, but it lasts for weeks only instead of months. 
Other beautiful old summer roses are the maiden's blush, the Portland rose, the rose unique, and the rose Celeste. But no rose, taking all the good qualities of a rose together, its hardiness, free blooming, beauty, and scent, will surpass the Gloire de Dijon, though the golden cups of Marshal Niel may be richer in colour, and the fragrance of La France recalls, as no other rose does, the luscious fragrance of Oriental otto of roses.

And now, instead of ordinary bedding-out, let me suggest some garden-beds which are far more effective. One is a bed of Lilium auratum, with heliotrope to fill up the spaces. Another is Agapanthus umbellatus, surrounded by Lobelia cardinalis. Then there should be beds of cannas, of gladiolus, of Clematis Fackmanni trained over withies, of zinnias, of the new hybrid begonias, and of asters. Somewhere room should be found for a border of everlastings, and somewhere for a row of the large red linum. One border may be given up to annuals, and it is no bad plan to mix the seeds of some twenty varieties, and let them 
grow up together as they will. The blue cornflower should have a piece of ground to itself, and so of course should the carnations. The white pinks will already have perfumed the herbaceous border with their aromatic scent, and the sweetwilliam and antirrhinum will also have claimed a place. The convolvulus major should have a chance of climbing upon a trellis, and the large nasturtium of trailing over a bank; and where the Tropeolum speciosum, which is one of the great ornaments of the gardens at Minto and elsewhere in Scotland, can be made to flourish in our English garden, it will be found as beautiful as either.

Above all, no garden should be without its hedge of sweet peas. If the pods are diligently pulled off, new flowers will be as constantly thrown out, and the "purfled scarf" of blossoms will remain in beauty till the first killing frost. It is easy to get a dozen different shades of colour, and nothing can look gayer, or give a more delicious scent. Keats-than whom no poet ever described flowers more accurately-speaks of the sweet pea's 
"wings of gentle flush o'er delicate white," and of its "taper fingers catching at all things."

Clumps of hollyhock, crusted over with bloom, should be planted near a sundial, or (as says the author of the well-known essay on "The Poetry of Gardening"), "in a long avenue, the double and the single, not too straitly tied, backed by a dark thick hedge of old-fashioned yew."

Sunflowers, also in clumps, should stand out here and there, and though the modern sceptics may tell us that this American plant cannot be the Clytie of Grecian story, it amply vindicates its name by its large discs, surrounded by golden rays. Tritomas should hold up their scarlet maces to the sun, among tufts of the Arundo conspicua, or (better still, if possible) of Pampas grass. Lastly, we must not forget to plant, for the sake of their delicious scent, as the summer evening falls, the curious Schizopetalon, and the better known Mathiola, or night-scented stock.

But, besides its flowers, the garden is alive with other happy forms of life. The blackbird, as the 
Laureate tells us, will "warble, eat, and dwell" among the espaliers; and the thrush, as Mr. Browning reminds us, "sings each song twice over" from some blossoming pear-tree. Then the bees are busy all summer long, rifling for themselves the flowers, and setting for us the fruit. "The butterflies flutter from bush to bush, and open their wings to the warm sun," and a peacock or red admiral, or better still, a humming-bird moth, is always a welcome guest. Only the other day I heard a delightful story (I wish I were satisfied that it was a fact) of a lady who got some chrysalises of butterflies from Italy and elsewhere, and, planting in a corner of her garden the herbs and flowers in which they most delighted, had hovering around, for many weeks of summer, these beautiful strange visitors from the south.

One great charm of a garden lies in the certainty that it will never be the same two years running. If we were only confident that each year was to be precisely like the last, it may fairly be doubted whether we could feel the same 
interest in our task. It is really no paradox to say, that it is fortunate that gardening should be always more or less of a struggle, for the very struggle, as should always happen, has the element of pleasure about it. Each year there will be success on one side, if something of failure on another. And there are always difficulties enough. There are difficulties arising from bad seasons, from climate, or from soil. There are weeds that worry, and seeds that fail. There are garden pests of every variety. The mice nibble away the tulip-bulbs: the canker gets into the rosebud, and the green fly infests the rose. Wireworms destroy the roots of tender annuals, and slugs breakfast upon their sprouting leaves. Moles and birds and caterpillars have each and all their peculiar plans for vexing the gardener's heart. Then again certain plants are attacked by special diseases of their own. The gladiolus turns yellow and comes to nothing, and a parasitic fungus destroys the hollyhock. And yet, if there were no difficulties to contend against, no forethought to be exercised, no ingenuity to be 
displayed, no enemies to conquer, it is surely impossible that we could feel the same pleasure and personal triumph in our success. Then, too, each year the intelligent gardener will arrange new combinations, grow new varieties of plants, and aim after a perfection which he can never hope to reach.

But the garden has no less also a scientific interest. Fresh species of plants are continually enriching our flower-beds, and botanists are constantly searching the wildest and most remote corners of the world on behalf of the English stove-house, conservatory, and garden. They endure untold hardships, and risk many dangers, if only they may secure some new treasure. Often they have caught deadly fever or met with fatal accidents in their search, and, true martyrs of science as they are, they pass away forgotten, except perchance when some unwonted designation of a plant may recall, not their memory indeed, but their name. But as one drops off, another will succeed; and so, among far coral islands of the Pacific, in the 
tropical recesses of a South American forest, in the heart of Asiatic mountains, or the unexplored mysteries of New Guinea, these lovers of nature are at work, labouring for our pleasure and instruction, and procuring for us new forms of vegetable life and beauty. And meanwhile science is working at home in another and a happier way. Not content with finding new species of plants, she is for ever developing fresh varieties. The art is no new one, and in old days the simpler minds of men were not quite sure of its propriety. It was unnatural, they used to say. It is in vain that Polixenes tells Perdita that there is an art that does mend nature, and, therefore, is nature. She evidently thinks it all sophistry, and not a gillyflower will she have.

\section{"I'll not put}

The dibble in the earth to set one slip of them."

And so, too, Andrew Marvell's mower complains of the gardener that

" The pink grew then as double as his mind;

The nutriment did change the kind;

With strange perfumes he did the roses taint,

And flowers themselves were taught to paint." 
He thinks it a wicked extravagance, as it certainly was, to sell a meadow for the sake of a tulip root, and he thinks it an absurdity, as it certainly was not, that we should have brought the "Marvel of Peru" over so many miles of ocean; but all this might be forgiven, but not the "forbidden mixtures" which grafting and hybridizing have brought about. Meanwhile, as we are now untroubled by such scruples, we may not only enjoy the results of the art of the skilful florist, but may even take an intelligent interest in the art itself. It lets us into many secrets of nature. It helps to explain problems of much higher significance than the brief existence of a garden flower. It makes us understand, in some small degree, how, in every form of life, a higher type may be produced from one of inferior order.

And the results are really wonderful. It is difficult to know what class of plants has in late years most profited by the artful nature, or unnatural art, of the skilful gardener; but certainly, some of the most striking successes 
have been among roses, clematis, begonias, and rhododendrons.

But it is not the florist only who has been helping on the cause of botanical science at home. Within the last few years the botanists, or rather perhaps the naturalists, have been increasingly busy among both the English field and garden flowers. The old botanists indeed had examined with every minuteness the structure and economy of the blossoms, had counted the stamens and the pistils, and known the origin of the swelling of the seed-vessel. And what Linnæus had systematized, Erasmus Darwin endeavoured to turn into a romance. Science was to be made popular in a long didactic poem, and The Loves of the Plants was the curious result. But to treat the various organs of a plant as if they were human beings and endowed with human passions, was obviously too far-fetched a conceit to give real pleasure, and it was not wonderful that Mathias, and many others, should have laughed at those, who

"In sweet tetrandrian monogynian strains Pant for a pistil in botanic pains." 
And then the illustrators took the matter up, and in Thornton's New Illustrations of the Sexual System of Linnous, which is perhaps one of the most beautiful botanical works ever published, we have pictures of plants with Cupid aiming a shaft at them, and with a letterpress of love-verses. Into the new system introduced by Jussieu, and now generally adopted for purposes of classification, we need not enter. The Natural system, as it is called, which is certainly the sensible system, has now held its own for many years, though the more artificial system of Linnæus has still its use and votaries.

The most recent investigators into botanical science are not classifying plants, but they are examining into the meaning of their structure. The mere task of description and enumeration has been done, and so they have set themselves to find out why certain structures exist, and why certain habits (if we may use the word) have been formed. Why do the climbing plants climb at all? and why do some twine, and others cling? 
Why do the fly-catching plants cause the death of numbers of unlucky insects? Why are the stamens and pistils in plants of such various lengths and sizes? Why have some flowers a hairy fringe, and others drops of nectar in their calyces? What is the meaning of the scent of flowers, and what is the object of the nightopening flowers? The key to many of these questions is in the relationship of flowers to insects; and Charles Darwin, Sir John Lubbock, and others, have done very much to explore and then to popularize the subject. Much that is most important has thus been made known to us, but these eminent naturalists would be the first to own that there is much more still to do. The secrets of nature open out but slowly, and after long and patient wooing. It would sometimes appear too as if there might be danger, not indeed of adapting facts to theory, but of taking it too readily for granted that all facts must eventually fit into some favourite theory. This tendency may not be so apparent in the leaders as in their less cautious disciples in these 
scientific researches. From some of their expressions they would almost seem to imply that insects were made for the sake of fertilizing flowers. They attribute the bright colour and beauty of flowers not to the same good purpose that gives beauty elsewhere, but as if it were merely that insects may be attracted, and do their duty among the ripening pollen. They are contemptuous at the idea of a flower being intended for the selfish pleasure of man and not for its own purposes, and they point to plants of beauty that "blush unseen" where man cannot admire them, forgetting, however, that man has seen them, or he would not know of their existence. They will learn nothing of the affluence of nature, and nothing is quite accepted unless its use can be established, though on this principle it is hard to explain why, as Bishop Hall pointed out long ago, "there is many a rich stone laid up in the bowels of the earth, many a faire pearle laid up in the bosome of the sea, that never was seen, nor never shall be."

It is curious how apparent extremes will meet. 
The very men who would most readily throw over the old theological argument of "design," which believed that everything was done in the most perfect way for the most perfect ends, will now in the interests of evolution show the necessity for each curve of a flower-cup and for each marking on a petal. We cannot be too thankful to them, if only they will make their ground sure at every step; but it will not do to generalize too rapidly. For instance, it has been stated that veins on a flower are probably guides to lead insects down into the honey-cup below, and that night-blowing flowers are without them because at night they would be invisible and useless. Unfortunately, it has since been shown that the Enothera taraxicifolia, and probably other night-flowers, are deeply marked with veins. Again, why in some cherry-blossoms is the pistil longer than the stamens, so that the fertilization must be effected differently to what it is in the more ordinary varieties, where the stamens and pistil are of equal length? Why have blossoms gradually developed properties to 
attract insects, when it is obvious that those properties were not originally required for the perpetuation of the species? Why should some flowers of magnificent size, like the magnolia, require scent to attract insects, if we must indeed admit that use and not pleasure is the end and aim of every attraction of the garden? And if scent is necessary in this case, why is it not so where the flower is small and insignificant? Why among roses has La France a delicious perfume, and Baroness Rothschild none?

But such questionings are inevitable as yet: meanwhile facts are accumulating, and the whole truth, thanks to the patient and laborious workers of our time, may one day be known.

But quite apart from scientific interests, a real old garden, unaltered and unspoiled, has a peculiar interest of its own. It is sure to be haunted by associations, and nothing calls up associations so quickly and certainly as a sudden scent of flowers coming and going upon the summer air. Time and change may have been busy since some long-absent member of the family has revisited 
his old home, but the flowers and their fragrance, still the same as ever, will call up all the past. There is the corner where the first violets were always found; there is the rosebush from which a flower may once have been gathered of which the poor faded petals still remain; there is the lavender, which supplied the oaken presses where the house-linen was always kept. And, apart from all such fond and foolish private memories, there are all the associations with which literature has consecrated the old garden-flowers. Pelargoniums, calceolarias, verbenas, and the rest of the new-comers have but few friends, but not an old flower but is "loaded with a thought," as Emerson says of the asters on the slopes at Concord. Roses, lilies, violets, primroses, and daffodils, have been written about over and over again, and the words of great poets rise unbidden to the memory at sight of them. And then certain flowers will recall an entire scene, and Marguerite asks her fate from the large white daisy whose name she bears, or Corisande, in her garden of every perfume, gathers-but not for herself-her choicest rose. 
While a garden owes so much to the poet's pen, it is strange that it should owe comparatively little to the artist's brush. Who can recall a single picture of gardens or of flowers that ever gave him any great amount of pleasure! Is Watteau an exception? But it is the figures in the foreground, not the garden, for which one really cares. And of flower-painters, there are Van Huysum and the Dutchmen, with their piles and masses of blossom, of large size, but generally of dull colour, and without light or warmth about them. Then there are our English flowerpainters; with some the flowers are only subsidiary to the picture, and they seem to have adopted Gilpin's advice that

" By a nice representation of such trifles, he [the painter] would be esteemed puerile and pedantic. Fern-leaves perhaps, or dock, if his piece be large, he might condescend to imitate; but if he wanted a few touches of red or blue or yellow, to enliven and enrich any particular spot on his foreground, instead of aiming at the exact representation of any natural plant, he will more judiciously give the tint he wants in a few random general touches of something like nature, and leave the spectator, if he please, to find out a resemblance. Botanical precision may please us in the flowerpieces of Van Huysum, but it would be paltry and affected in the landscapes of Claude or Salvator." 
But even when the flower or plant is something better than a "touch" of colour, there is often some gross carelessness, or ignorance, which gives a sense of annoyance rather than of pleasure. Each returning year, the Gardeners' Chronicle reviews the Royal Academy from a botanical point of view, and nothing can be droller than the blunders it points out. Sometimes all sorts of flowers of various seasons are growing together, or a wood, through which a knight is riding, is adorned with agarics and fungi that belong to different periods of the year. Sometimes places, no less than times, are set at nought, as in an instance quoted by Mr. Rossetti from the Exhibition of I 868, where a Greek maiden is gathering blossoms from a pot of (American) azaleas. But, indeed, such instances are only too common. In how many modern classical pictures, for example, has not the large sunflower of America been introduced? But when the flower itself is one important part of the picture, how curiously unsatisfactory is too often the result! No one has tried more earnestly to set our painters right in 
these matters than Mr. Ruskin, and how little even now have they profited by his teaching: They catch hold of a suggestion, as when he once told them (showed them, we might say) that a spray of pink apple-blossom against a blue sky was beautiful, and the next exhibition or two abounded in blossoming apple-boughs: but they seem unable to grasp a principle. It was in $185 \mathrm{I}$, in his tract on "Pre-Raphaelitism," that he urged the painting of "the heather as it grows, and the foxglove and the harebell as they nestle in the clefts of the rocks;" and this last: year, while speaking of the same artist, Mr. Hunt, he has had to repeat the same lesson, that plants that grow are pleasanter objects than flowers that are gathered. And, indeed, the reason is not far to seek. A bunch of garden-roses thrown carelessly down upon a mossy bank-and there is scarcely an exhibition without one-not only gives one a feeling of incongruity (as though the fashionable flowers were out at a picnic), but a stronger feeling still of coming death. We know those roses must wither and die, almost, we fancy, as 
we look upon them. No dew that falls can now keep them alive, as it will the humble moss-so much better than they-on which they rest. And it is almost worse when the poor gathered flowers are brought indoors and placed in some blue jar or Salviati vase, and the artist shows how carefully he can draw, not so much the petals of the flowers as the texture of the porcelain or the iridescence of the glass. It is difficult enough worthily to paint the light and glow of colour in any beautiful flower, but, if it is to be painted, let it be when the plant is still growing, and as it grows. Any garden will give subjects enough, if they are only sought for. Here is a bank of daffodils; here the white narcissus and the red anemone have formed a group; here a blue forget-me-not looks up into the bell of the snake's-head fritillary; here is a great peony bowed down with its crimson globes; here a nasturtium trails its bright yellow blossoms along a bit of grey old rock; here a cluster of hollyhocks keep watch by a garden walk; here the purple clematis clings to the orchard hedge. 
Pictures of flowers such as these, if only the artist have some sense of colour and some refinement of taste, would give a real and almost a new pleasure to us all.

But there must be no artistic grouping, or representing of things as they should be rather than as they are. The work must be conscientious, as in the case of a great living sculptor who, having to carve an ivy plant upon a tablet, went himself to study the form of growing ivy, and found how entirely different it is from the conventional wreaths of the ordinary marblemason.

There is one question in connection with English horticulture to which at first sight it does not seem quite easy to give a satisfactory answer. Are the flower-shows, the number of which is constantly increasing, an advantage or not? They certainly stimulate the production of magnificent fruit, of beautiful florist-flowers, and of handsome stove and greenhouse plants. But how do they affect the gardens in which these prize specimens are grown? It is mere matter of fact that, when 
a gardener begins to think of exhibiting, he is very apt to pay undue attention to the plants which will secure him prizes and reputation. If his master is satisfied with the usual monotony of garden-beds, why should the gardener give special attention to what can be of no service to himself? So he throws his whole strength into some bunches of grapes, some dozen roses, some trained chrysanthemums. And this is not the worst of it. The "dressing" of particular blooms has recently become an art, and little curlingirons are employed to get petals into their proper shape, and other various devices are used for various flowers. But there is after all a morality in these things. It is allowable to cut away superfluous petals, but it is not allowable to insert fragments of another blossom. This seems to be the limit. Now we confess the whole system seems to us thoroughly bad, and we recommend the managers of flower-shows to forbid "dressing" of every kind. If not exactly dishonest in itself, it leads on, and very easily, to the worst forms of dishonesty. But indeed, 
in almost every aspect, nothing can be more spoiling to the gardener than these flower-shows so constantly are. In the first place, the prizeticket generally asserts that the prize is adjudged to "Mr. —, gardener to ——." The owner of the garden is nobody, and the gardener is everything. The prize is in almost every case regarded as the unchallenged property of the gardener, who has, nevertheless, won the prize by his master's plant, reared at his master's expense, and at the cost of time which has made him, too frequeritly neglect much more important matters.

Is it any wonder if horticulture in its best sense - that is, the culture of the garden as a wholeis not what it should be? No gardener can get prizes for well-kept beds, for effects of harmonious colouring, for arrangement of shrubberies, for the grouping of herbaceous plants. $\mathrm{He}$ is tempted for the sake of a single specimen to sacrifice the beauty of a whole plant, or the clusters of an entire fruit-tree. That it is most important for nurserymen to be able to compare new species, 
or new varieties of old species, is of course undeniable. That our ordinary flower-show is for the ordinary spectator an extremely pretty sight is no less certain. But we are satisfied that in the majority of cases it is the wiser course for any one who really cares about his garden, and would rather have a succession of well-cultured flowers than some merely exceptional success, to discourage his gardener from exhibiting.

In conclusion, I can only repeat that "the English flower-garden" may afford far greater pleasure than it does at present. We must learn to look on plants, not as mere points of colour, but as old friends on whose coming we can rely, and who, returning with the recurring seasons, bring back with them pleasant memories of past years. And if, as often happens, they are plants consecrated by song or legend, the imagination is quickened as surely as the heart is stirred. We must remember, too, that our personal delight in a garden is entirely independent of its size or the perfection of its appliances. A child's garden, such as Mary Howitt once 
described, a few pots of musk or mignonette on the window-ledge of a schoolboy's study, will afford a pleasure which acres of garden, left only to the gardener's care, can never give. "How can I care for this garden? It is so much too large to care about"-a lady, who owns one of the famous gardens in the north of England, once said to me; and it was impossible not to appreciate the difficulty.

Indeed, as with everything else, the garden will soon grow dull, and the flowers lose their attraction, unless we take the management, partly at least, into our own hands, and be masters not in name but in reality. It is not necessary to understand every matter of detail, though our interest will strengthen as our practical knowledge grows; but at least we may make up our minds as to what we want to have done, and then take care that the gardener carries out our orders. We are too often the absolute slaves of our gardeners, and they in turn (of course I am not speaking of exceptions) are too often the slaves of an unintelligent routine. We have 
learnt, as Bacon said, "to build stately sooner than to garden finely, as if gardening were the greater perfection." It is really about time that we learnt the more difficult lesson. 


\section{N O T E S.}

\section{NOTE I.}

THE GARDENER BOWER-BIRD.

THIs curious bird was first described by Schlegel, and a coloured illustration of its garden and bower will be found in Gould's Birds of Nerw Guinea. The fullest account, however, seems to be that of Signor Beccari, which first appeared in a scientific periodical of Genoa. It was translated for the Gardeners' Chronicle of March II, I878, and I am permitted to make use of the very interesting narrative:

"The Amblyornis inornata-or, as I propose to name it, the Bird-gardener-is a Bird of Paradise of the dimensions of a turtle-dove. The specific name 'inornata' well suggests its very simple dress. It has none of the ornaments common to the members of its family, its feathers being of several shades of brown, and showing no sexual differences.

"It was shot some years ago by the hunters of Mynheer von Rosenberg. The first descriptions of its 
powers of building (the constructions were called 'nests') were given by the hunters of Mynheer Bruijn. They endeavoured to bring one of the nests to Ternate, but it was found impossible to do this, both by reason of its great size and the difficulty of transporting it.

"I have fortunately been able to examine these constructions at remote places where they are erected. On June 2o, I875, I left Andai for Hatam, on Mount Arfak. I had been forced to stay a day at Warmendi to give rest to my porters. At this time only five men were with me; some were suffering trom fever, and the remaining porters declined to proceed. We had been on our way since early morning, and at one o'clock we intended to proceed to the village of Hatam, the end of our journey.

"We were on a projecting spur of Mount Arfak. The virgin forest was very beautiful. Scarcely a ray of sunshine penetrated the branches. The ground was almost destitute of vegetation. A little trackway proved that the inhabitants were at no great distance. A limpid fountain had evidently been frequented. I found here a new Balanophora, like a small orange or a small fungus. I was distracted by the songs and the screams of new birds, and every turn in the path showed me something new and surprising. I had just killed a small new marsupial (Phascelogale dorsalis, Pet, and Doria), that balanced itself on the stem of a great tree like a squirrel, and turning round, I suddenly stood before the most remarkable specimen of the industry of 
an animal. It was a hut or bower close to a small meadow enamelled with flowers. The whole was on a diminutive scale. I immediately recognised the famous nests described by the hunters of Bruijn. I did not suspect, however, then, that they had anything to do with the constructions of the Chlamydodeæ. After well observing the whole, I gave strict orders to my hunters not to destroy the little building. That, however, was an unnecessary caution, since the Papuans take great care never to disturb these nests or bowers, even if they are in their way. The birds had evidently enjoyed the greatest quiet until we happened, unfortunately for them, to come near them. We had reached the height of about 4,800 feet, and after half an hour's walk we were at our journey's end."

The Nest.

"I had now full employment in the preparation of my treasure, and I gave orders to my people not to shoot many of the birds. The nest I had seen first was the nearest one to my halting-place. One morning I took colours, brushes, pencils, and gun, and went to the spot. While I was there neither host nor hostess were at home. I could not wait for them. My hunters saw them entering and going out, when they watched their movements to shoot them. I could not ascertain whether this bower was occupied by one pair or by several pairs of birds, or whether the sexes were 
in equal or unequal numbers-whether the male alone was the builder, or whether the wife assisted in the construction. I believe, however, that such a nest lasts for several seasons.

"The Amblyornis selects a flat even place around the trunk of a small tree, that is as thick and as high as a walking-stick of middle size. It begins by constructing at the base of the tree a kind of a cone, chiefly of moss, of the size of a man's hand. The trunk of the tree becomes the central pillar, and the whole building is supported by it. The height of the pillar is a little less than that of the whole of the hut, not quite reaching two feet. On the top of the central pillar twigs are then methodically placed in a radiating manner, resting on the ground, leaving an aperture for the entrance. Thus is obtained a conical and very regular hut. When the work is complete many other branches are placed transversely in various ways, to make the whole quite firm and impermeable. A circular gallery is left between the walls and the central cone. The whole is nearly three feet in diameter. All the stems used by the Amblyornis are the thin stems of an orchid (Dendrobium), an epiphyte forming large tufts on the mossy branches of great trees, easily bent like straw, and generally about twenty inches long. The stalks had the leaves, which are small and straight, still fresh and living on them; which leads me to conclude that this plant was selected by the bird to prevent rotting and mould in the building, since it keeps alive for a 
long time, as is so often the case with epiphytical Orchids.

"The refined sense of the bird is not satisfied with building a hut. It is wonderful to find that the bird has the same ideas as a man, that is to say, what pleases the one gratifies the other. The passion for flowers and gardens is a sign of good taste and refinement. I discovered that the inhabitants of Arfak, however, did not follow the example of the Amblyornis. Their houses are quite inaccessible from dirt."

\section{The Garden.}

"Now let me describe the garden of the Amblyornis. Before the cottage there is a meadow of moss. This is brought to the spot and kept free from grass, stones, or anything which would offend the eye. On this green turf, flowers and fruits of pretty colour are placed so as to form an elegant little garden.

"The greater part of the decoration is collected round the entrance to the nest, and it would appear that the husband offers there his daily gifts to his wife. The objects are very various, but always of vivid colour. There were some fruits of a Garcinia like a small-sized apple. Others were the fruits of Gardenias of a deep yellow colour in the interior. I saw also small rosy fruits, probably of a Scitaminaceous plant, and beautiful rosy flowers of a splendid new Vaccinium (Agapetes Amblyorninis). There were also fungi and mottled 
insects placed on the turf. As soon as the objects are faded they are moved to the back of the hut.

"The good taste of the Amblyornis is not only proved by the nice home it builds. It is a clever bird, called by the inhabitants Buruk Gurea-(master bird),since it imitates the songs and screamings of numerous birds so well that it brought my hunters to despair, who were but too often misled by the bird. Another name of the bird is Tukan Robon, which means a gardener."

NOTE II.

ARS TOPIARIA.

THE Romans used the word Topiarius for their ornamental gardener, and one of his chief duties-the Ars topiaria in fact-was to cut the shrubs, and especially box-trees, into figures of ships, animals, and names. There is a well-known passage in one of the letters of the younger Pliny, in which, while speaking of his garden, he describes "a sort of terrace, embellished with various figures, and bounded with a boxhedge, from which you descend by an easy slope, adorned with the representation of divers animals in box answering alternately to each other, into a lawn overspread with the soft, I had almost said the liquid, acanthus : this is surrounded by a walk, enclosed with 
tonsile evergreens, shaped into a variety of forms. Beyond it is the gestatio [a sort of avenue in which to take exercise] laid out in the form of a circus, ornamented in the middle with box cut in numberless different figures, together with a plantation of shrubs prevented by the shears from running up too high; the whole is fenced in with a wall, covered by box, rising by different ranges to the top." Further on he says, "Having passed through these several winding alleys, you enter a straight walk, which breaks out into a variety of others, divided off by box-hedges. In one place you have a little meadow; in another the box is cut into a thousand different forms, sometimes into letters expressing the name of the master, sometimes that of the artificer, whilst here and there little obelisks rise intermixed alternately with fruit-trees." I Martial too gives a curious illustration of the Ars topiaria. A grove of Plane trees was adorned with topiarian wild beasts, - among them a bear; a young boy thrust his hand into the bear's wide mouth, and a viper hiding there stung him to death. What a misfortune, adds Martial, that the bear had not been a real one. This Ars topicria had been for some time in fashion in England when Addison first attacked it in the Spectator of June 25th, 1712: "Our British gardeners, on the contrary, instead of humouring nature, love to deviate from it as much as possible. Our trees rise in cones, globes, and pyramids. We see the marks of the scissors upon every plant and bush. I do not

${ }^{x}$ I have adopted Frofessor Amos's translation. 
know whether I am singular in my opinion, but, for my own part, I would rather look upon a tree in all its luxuriancy and diffusion of boughs and branches than when it is thus cut and trimmed into a mathematical figure."

But this is nothing to the denunciation by Pope, which may be found in the Guardian of September 29 th, I 7 I 3 . It is extremely humorous. He declares that

"A citizen is no sooner proprietor of a couple of yews, but he entertains the thought of erecting them into giants, like those of Guildhall. I know an eminent cook, who beautified his country-seat with a coronation dinner in greens, where you see the champion flourishing on horseback at one end of the table, and the queen in perpetual youth at the other. For the benefit of all my loving countrymen of this curious taste, I shall here publish a catalogue of greens to be disposed of by an eminent town gardener, who has lately applied to me on this head. He represents, that for the advancement of a politer sort of ornament in the villas and gardens adjacent to this great city, and in order to distinguish those places from the more barbarous countries of gross nature, the world stands much in need of a virtuoso gardener, who has a turn for sculpture, and is thereby capable of improving upon the ancients in his imagery of evergreens. I proceed to his catalogue:

"Adam and Eve in Yew; Adam a little shattered by the fall of the Tree of Knowledge in the great storm; Eve and the Serpent very flourishing. 
"Noah's Ark in Holly, the ribs a little damaged for want of water.

"The Tower of Babel, not yet finished.

"St. George in Box, his arm scarce long enough, but will be in a condition to stick the Dragon by next April.

"A green Dragon of the same, with a tail of groundivy for the present. N.B. These two not to be sold separately.

"Edward the Black Prince in Cypress.

"A Laurustine Bear in blossom, with a Juniper Hunter in berrie.

"A pair of Giants stunted ; to be sold cheap."

And there are various other lots equally remarkable and interesting.

But the topiarian art has never been either scolded or laughed entirely out of existence, and we all remember how many years later when Lovel first visits "The Antiquary" he found the house of Monkbarns "surrounded by tall clipped hedges of yew and holly, some of which still exhibited the skill of the topiarian artist, and presented curious arm-chairs, towers, and the figures of St. George and the Dragon. The taste of Mr. Oldbuck did not disturb these monuments of an art now unknown, and he was the less tempted so to do, as it must necessarily have broken the heart of his old gardener." 


\section{NOTE III.}

\section{A POET'S FLOWER-BED.}

THE quaintest of all devices in flower-beds was the one which Mrs. Browning-then Elizabeth Barrettmade for herself when a child. In after years she told the story of it in a poem, and I venture to extract some stanzas, as they may not be known to all my readers, and as they illustrate my subject rather curiously. Hope End, where Miss Barrett lived, and where this "Hector" flowered, was once well known to me. Crossing the Malvern Hills on the Herefordshire side, and passing the Colwall valley, you find the ground sloping up again into a little ridge. Here, hidden away in a side valley, was the strange-looking house, with Moorish pinnacles. Here was the pond where "little Ellie" found the "swan's nest among the reeds." And here the young girl of nine years old, who had already drunken so deeply of "the wine of Cyprus." formed her garden-bed in the shape of her hero Hector, while a laurel stood on a mound close by, and the birds sung in an old pear-tree which cast soft shadows on the ground:

" In the garden, lay supinely

A huge giant, wrought of spade !

Arms and legs were stretched at length, In a passive giant strength,And the meadow turf, cut finely, Round them laid and interlaid. 
" Call him Hector, son of Priam!

Such his title and degree.

With my rake I smoothed his brow;

Both his cheeks I weeded through :

But a rbymer such as I am

Scarce can sing his dignity.

" Eyes of gentianellas azure,

Staring, winking at the skies;

Nose of gillyflowers and box;

Scented grasses, put for locks-

Which a little breeze, at pleasure,

Set a-waving round his eyes.

" Brazen helm of daffodillies,

With a glitter toward the light ;

Purple violets, for the mouth,

Breathing perfumes west and south ;

And a sword of flashing lilies,

Holden ready for the fight.

" And a breastplate, made of daisies,

Closely fitting, leaf by leaf ;

Periwinkles interlaced,

Drawn for belt about the waist ;

While the brown bees, humming praises,

Shot their arrows round the chief."

\section{NOTE IV.}

THE EVENING PRIMROSE.

I wonder whether the Evening Primrose is as much grown and cared for as it deserves to be. It is an 
American plant, but is now found wild in several parts of England, notably at Formby, among the Lancashire sand hills, where tradition says it originally came from a vessel wrecked on that barren coast. It is mentioned little, if at all, by our old botanists, and our more modern poets have for the most part passed it carelessly by. Southey, however, alludes to it in his well-remembered lines to the bee, that was still at work, after the Cistus flowers had fallen and "the Primrose of Evening was ready to burst." Keats, too, has a striking passage about the Evening Primrose, which I quote a little further on, for I may perhaps make a few extracts from an article I lately wrote in the Pall Mall Gazette on "The Garden at Nightfall," as I have no better words in which to describe the beauty and charm of these CEnotheras. The question arising from the veins of flowers I have already mentioned in TheEnglish Flower Garden.

"I have two varieties of CEnotheras or Evening Primroses, and they are in their full glory to-night. One is the large flowering yellow Enothera, which grows from five to six feet high, and which opens its yellow blossoms night after night from early summer to late autumn. It is a curious sight to see the blossoms begin to open. I had been in the garden shortly after six, and the yellow buds were still folded within the calyx. Watching closely, you saw the petals give a sudden start-they half release themselves-and by degrees open out fully into the blossom, which will last till morning, but begins to fade after the sun has dried up the dews of night. 
Keats, whose accurate observation of flowers is often very remarkable, speaks of

'A tuft of evening primroses

O'er which the mind may hover till it dozes;

O'er which it well might take a pleasant sleep

But that 'tis ever startled by the leap

Of buds into ripe flowers.'

But more beautiful still than the yellow Enothera is the white Enothera taraxicifolia, the evening primrose of the dandelion leaf. I have a bed of standard roses which I have carpeted entirely with this Enothera. It grows low to the ground, and its leaves, which are deeply serrated, cover the bed. In the daytime there are the relics of the last night's harvest of blossom, but the flowers look faded, and soon get a pink flush over the white-after which they wither away. But to-night the fresh blooms are out, and I count from sixty to seventy of them, like stars, some in clusters and some gleaming singly from the mass of deep foliage. There is, it almost seems to me, a positive light about them which no other white flower has, not even the Eucharis or the Christmas rose. And then the blossoms are so large when fully open-at least three inches across the petals. This Enothera is from Chili, but the yellow one comes from North America; and a smaller yellow one, also from North America, may be found naturalized and now quite wild in one or two places in England. The name Enothera (properly, I suppose, Enothēra) is said to have been given because the root smelt of wine; but if 
it is uncertain what the Greek Enothera really was, certainly no old Greek could know anything of these beautiful blossoms of our Western night.

"Sir John Lubbock says that the evening primrose is probably fertilized by moths, and it would seem at first sight most likely that this should be the case. To-night - for the air, as I have said, is quite still and warm-is just the night that I should expect the moths to be at work; but after long waiting near a large yellow CEnothera (the one plant had forty blooms), I did not see one single moth. I returned to the bed of Enothera taraxicifolia, and again I could see no moth of any kind. Meanwhile, a little further off, among a bed of white Mediterranean heath, which is just as much in flower by day as it is now, there are several of these wanderers of the night-little brown moths of (I think) two different varieties. There and there alone, and not among the large open blossoms of the CEnotheras, or among the delicate tufts of night-scented stock, were the moths busily erigaged. Why, then, do these night-flowers-if it be not to attract night insects, and so get fertilized -expand their petals as evening falls? We have, I suspect, a good deal yet to learn on these matters. Even the two Enotheras are very unlike in several respects. The seed-vessel of the Enothera taraxicifolia is at the end of a long tube, some seven inches in length, down which runs the stalk or style of the pistil, and within this tube I have constantly found little black flies and grains of pollen. Moreover, the pistil and the 
stamens of this Enothera are as nearly as possible the same length; so that even before the flower has opened, a stigma or head of the pistil has got well dusted over with the pollen of the stamens.

"In the case of the large yellow Enothera the pistil stands out above the stamens, and I suppose it could not be fertilized except by the wind or (more probably) by insects. The tube that leads to the seedvessel is here only about two inches long, and is not smooth but hairy, so that insects would hardly pass down. Somehow or other, however, the yellow Enothera bears seed much more certainly and abundantly than the white one. I must add that the veins in both Enotheras, and especially in the white one, are very strongly marked; so that a theory which carries the high sanction of Sir John Lubbock, that veins are guides to the honey of a flower, and that they do not exist in night-opening flowers, as they would be unseen by night and therefore useless, can hardly, I imagine, be maintained."

I believe it is now pretty well ascertained that the Enothēra of the ancients was the small Willow-herb (Epilobium roseum), which in my own garden is the most familiar of weeds.

Pliny describes it as having exhilarating properties in wine, as having leaves like those of the Almond-tree, a rose-coloured flower, many branches, and a long root, which, when dried, has a vinous smell, and an infusion of which has a soothing effect on wild beasts. 
In Baptista Porta's curious Phytognomonica (published at the end of the sixteenth century) he says,- - speaking no doubt of this same Epilobium,- that the dried root of the Enothēra smells of wine; given as a drink it soothes wild beasts and makes them tame, and rubbed on the worst wounds it serves to heal them.

\section{NOTE V.}

THE CHRISTMAS ROSE.

The Christmas Rose is certainly one of the most valuable of flowers, but it is a little capricious, growing luxuriantly in one place, and in another gradually dwindling off. With me it is always successful, and one secret may be that the roots are never allowed to be disturbed. This beautiful flower has rather weird associations. It is the Black Hellebore of Pliny, and was used as a poison and in incantations. Spenser plants it with the "dead sleeping poppy" and all other sad and poisonous herbs in the garden of Proserpina. Often, however, it was valued for its medicinal qualities, and was occasionally, we are told, made use of by literary people for the purpose of sharpening up their intellects. Gerard says that "Black Hellebore is good for mad and furious men, for melancholike, dull, and heavie persons, for those that are troubled with the falling sickness, for lepers, for them that are sicke of quartaine ague, and briefly for all those that are troubled with blacke choler, and molested with melancholie." Cowley, too, has a curious poem, in which the Christmas-flower (as he calls it) speaks, and 
boasts that, alone of flowers, Winter "still finds me on my guard," though the ground is " covered thick in beds of snow," and then it sounds its triumphs over all sorts of ills, physical and mental :

"I do compose the mind's distracted frame,

A gift the gods and I alone can claim."

Old Dr. Darwin, in his Loves of the Plants, has a scientific interest of quite another kind in the Christmas Rose :

" Bright as the silvery plume, or pearly shell, The snow-white rose, or lily virgin bell, The fair Helleboras attractive shone, Warmed every Sage, and every Shepherd won," but, when the seed-vessel begins to swell, " Each roseate feature fades to livid green."

He adds, in a note, that "The Helleborus niger, or Christmas Rose, has a large beautiful white flower, adorned with a circle of tubular two-lipp'd nectaries. After impregnation the flower undergoes a remarkable change, the nectaries drop off, but the white corol remains, and gradually becomes quite green. This curious metamorphose of the corol, when the nectaries fall off, seems to show that the white juice of the corol were before carried to the nectaries for the purpose of producing honey, because, when these nectaries fall off, no more of the white juice is secreted in the corol, but it becomes green, and degenerates into a calyx."

Dr. Darwin's theory may or may not be strictly accurate, but his observation of facts is certainly undoubted. 
In one of Keats's early poems he notices the Hellebore's curving leaf,

" As the leaves of Hellebore

Turn to whence they sprung before,

And beneath each ample curl

Peeps the richness of a pearl!"

But if poets know how to describe a Christmas Rose, there are others who do not. A horticultural book just published, says - and the description is a curiosity-that in the month of January, "in our garden, on the hillside, the Christmas Rose is the sweetest and prettiest thing to show. Its petals are weak and pale; its per. fume is very faint ; if you gather it, the leaves presently fall off, and the flower is destroyed. Leave it in the hedge, when it is almost the only thing to gladden the eye :

“ The Christmas Rose, the last flower of the year, Comes when the holly berries glow and cheerWhen the pale snowdrops rise from the earth, So white and spirit-like 'mid Christmas mirth."

I wish the writer would show me this curious Christmas Rose, which grows in a hedge, and has weak petals and a faint perfume, and is spirit-like! What can it be? and who could have written these very unmelodious lines?

THE END. 
Second Edition. Crown 8vo. 3s. 6 d.

\section{BY THE SAME AUTHOR.}

\section{A Y E A R}

IN

\section{A LANCASHIRE GARDEN.}

"It is full of admirable suggestions for the practical gardener as to the choice and arrangements of his plants; but it will also be read with interest in the arm-chair in town. It is the true story of a year's gardening written by an accomplished man, whose flowers tell him many stories and pleasant things not to be found in the nurseryman's catalogue. . . A faithful and fascinating garden story."-The Times.

"Those who want a pleasant, chatty companion, who never bores, but who is so well informed that the meanest weed seems to recall to his mind the choicest flowers of the garden of literature will do well to consult Mr. Bright's pages."-Athenaum.

"A volume written not for gardeners alone but for as many as love the scent, the sight, or the associations of flowers." -The Graphic.

"Quaint reflections, apt quotations, and scraps of classical lore are interspersed through the text in a very pleasant fashion. The volume is, therefore, admirably adapted for lazy reading during the hot summer months."-The Globe. 


\section{Messrs. MACMILLAN \& CO.'S PUBLICATIONS.}

\section{FLORAL DECORATIONS FOR THE DWELL-}

ing-house. A Practical Guide to the Home Arrangement of Plants and Flowers: By AnNe Hassard. With numerous Illustrations. Crown 8 vo. $5 s$.

"A book which cannot fail to be useful to those who need advice on such subjects. It is thoroughly practical, comprehends all that one needs to know."-Athenaum.

"The authoress has performed her task so well as to have pr duced a real work of art for which many a mistress of a household will be thankful."-Standard.

BY THE

REV. HUGH MACMILLAN, LL.D., F.R.S.E. TWO WORLDS ARE OURS. Globe 8vo. $6 s$. BIBLE TEACHINGS IN NATURE. Thirteenth Edition. Globe 8vo. 6s.

THE MINISTRY OF NATURE. Fifth Edition. Globe 8vo. 6s.

THE TRUE VINE; OR, THE ANALOGIES OF OUR Lord's Allegory. Fourth Edition. Globe 8vo. 6s.

"It abounds in exquisite bits of description, and in striking facts. cleariv stated. . . We have read the book with not a little pleasure and can rec mmend it."-Nonconformist. HOLIDAYS ON HIGH LANDS; OR, RAMBLES and Incidents in Search of Alpine Plants. Second Edition, Revised and Enlarged. Globe 8vo. $6 s$.

"A series of delightful lectures on the botany of some of the best known mountain regions."-The Guardian.

THE SABBATH OF THE FIELDS. BEING A Sequel to "Bible Teachings in Nature." Third Edition. Globe 8vo. $6 s$. FIRST FORMS OF VEGETATION. Second Edition, Corrected and Enlarged. With numerous Illustrations. Globe 8vo. $6 s$.

"'Mr. Macmillan's book is pleasantly written and well illustrated, and will be welcomed alike by the botanist or general reader."-Acalemy.

\section{BY HENRY TANNER, F.C.S.;}

Professor of Agricultural Science, University Colleee, Aberystwith, Examiner in the Principles of Agriculture under the Government Defartment of Science.

FIRST PRINCIPLES OF AGRICULTURE. $18 \mathrm{mo}$. Is.

THE ABBOTT'S FARM; OR, PRACTICE WITH Scrence, Crown 8vo. 3s $6 d$.

ELEMENTS OF AGRICULTURAL SCIENCE.

Fcap. 8vo.

[In the press. MACMILLAN \& CO., LONDON. 
Messrs. MACMILLAN \& CO.'S PUBLICATIONS.

\section{ART AT HOME SERIES.}

Edited by W. J. LOFTIE, B.A.

ART IN THE HOUSE. A PLEA FOR ART

IN THE HOUSE. With special reference to the Economy of

Collecting Works of Art, and the Importance of Taste in Education and Morals. By W. J. Loftie, B.A., F.S.A., Author of "In and Out of London." With Illustrations. New Edition. Crown 8vo. 2s. $6 d$.

HOUSE DECORATION. Suggestions for House Decoration, in Painting, Woodwork, and Furniture. By RHODA and Agnes Crarretr. With Illustrations. New Edition. Crown 8vo. $2 s .6 d$.

MUSIC IN THE HOUSE. By JOHN Hullah. New Edition. Crown 8vo. 2s. $6 d$.

THE DRAWING ROOM : ITS DECORATIONS AND FURNITURE. By MRs. ORRINSMITh. With numerous Illustrations. New Edition. Crown 8vo. 2s. $6 d$.

THE DINING ROOM. By Mrs. Loftie. With numerous Illustrations. New Edition. Crown 8vo. 2s. 6 d.

THE BED ROOM AND BOUDOIR. By LADY Barker. With numerous Illustrations. New Edition. Crown 8vo. 2s. $6 d$.

DRESS, By Mrs. Oliphant. With numerous Illustrations. Crown 8 vo. 2s. $6 d$.

AMATEUR THEATRICALS. By WALTER H. Pollock and I.Ady Pollock. Illustrated by Kate Greenaway. Crown 8vo. 2s. $6 d$.

NEEDlEWORK. By Elizabeth Glaister. Author of "Art Embroidery." Illustrated. Crown 8vo. 2s.6d.

THE MINOR ARTS: PORCELAIN PAINTING WOOD CARVING, STENCILLING, MODELLING, MOSAIC WORK, \&c. By Charles G. Leland. Illustrated. Crown 8vo. 2s. $6 d$.

THE LIBRARY. By ANDREw LANG, with a Chapter on English Illustrated Books, by Austin Dobson. With numerous Illustrations. Crown 8vo. 3s. $6 d$.

** Al-o a limited Edition on large paper. Demy Svo. Ios. $6 d$. (Other volumes in preparation.) MACMILLAN \& CO., LONDON. 
Now publishing, in Crown 8vo, price $2 s .6 d$. each.

\section{ENGLISH MEN OF LETTERS.}

\section{Edited by JOHN MORLEY.}

\section{JOHNSON. By Leslie Stephen. Crown Svo. 2s. 6 d.}

“The new series opens well with M.r. Leslie Stephen's sketch of Dr. Johnson. It could hardly have been done better, and it will convey to the readers for whom it is intended a juster estimate of Johnson than either of the two essays of Lord Macaulay."-Pall Mall Gazette.

\section{SCOTT. By R. H. Hutton. Crown 8vo. 2s. $6 d$.}

"We could not wish for a more suggestive introduction to Scott and his poems and novels."-Examiner.

\section{GIBBON. By J. C. Morison. Crown 8vo. 2s. 6d.}

"As a clear, thoughtful, and attractive record of the life and works of the greatest among the world's historians, it deserves the highest praise." -Examiner.

SHelley. By J. A. Symonds. Crown 8vo. 2s. $6 d$.

"The lovers of this great poet are to be congratulated at having at their command so fresh, clear, and intelligent a presentment of the subject, written by a man of adequate and wide culture."-Athencum.

HUME. By Professor Huxley, F.R.S. Crown 8vo. 2.5. $6 d$.

"It may fairly be said that no one now living could have expounded IIume with more sympathy or with equal perspicuity."-Atheneum.

GOLDSMITH. By William Black. Crown 8vo. 2s. $6 d$.

"Mr. Black brings a fine sympathy and taste to bear in his criticism of Goldsmith's writings, as well as his sketch of the incidents of his life."Athencum.

DEFOE. By W. Minto. Crown 8vo. 2s. 6d.

"Mr. Minto's book is careful and accurate in all that is stated, and faithful in all that it suggests. It will repay reading more than once."Athenoum.

BURNS. By Principal Shatrp. Crown 8vo. 2s. $6 d$.

"It is impossible to desire fairer criticism than Principal Shairp's on Burns' poetry. . . . None of the series has given a truer estimate either of character or of genius than this volume."-Spectator. 
SPENSER. By the Very Rev, the DeAn of St. Paul's. Crown 8vo. 2s. $6 d$.

"Dr. Church is master of his subject, and writes always with good taste."-Academy.

THACKeRAY. By Anthony Trollope. Crown Sro. 2s.6 $d$.

"Mr. Trollope's sketch is excellently adapted to fulil the purpose of the series in which it appears." -Athenoum.

BURKE. By John Morley. Crown Svo. 2s. $6 d$.

"It is no disparagement to the literary studies already published in this admirable series, to say that none of them have surpassed, while few have equalled, this volume on Burke."-British Quarterly Review.

milton. By Mark Pattison. Crown 8vo. 2s. $6 d$.

"The writer knows the times and the man, and of both he has written with singular force and discrimination."-Spectator.

HAWthorne. By Henry James, Junr. Crown 8vo. $2 s .6 d$.

"Probably no one living could have done so good a book on Hawthorne as Mr. James has done."-Saturday Review.

SOUTHEY. By Professor Dowden. Crown 8vo. 2s. $6 d$.

"A truly scholarly and delightful monograph of a great writer, who has been of late years undeservedly neglected."-Examiner.

CHAUCER. By Professor A. W. WARd. Crown 8vo. 2s. $6 d$.

"An enjoyable and excellent little book is this of Professor Ward's. Far away the best connected account of Chaucer and his work to be found in English."-Acadenny.

BUnyan. By James A. Froude. Crown 8vo. 2s. 6 .

"The life and character of Bunyan stand out in bold relief, and for the firct time the author of the 'Pilgrim's Progress' is pourtrayed as he really existed."-Westminster Recicio. 


\section{POPE. By Leslie Stephen. Crown 8vo. 2s. 6 d.}

"The sketch of Pope's life which Mr. Leslie Stephen has written is interesting throughout. . . A work which one can only lay down with a wish to have a good deal more on the same subject from the saiue hand." -Academy.

\section{BYRON. By Professor Nichol. Crown 8vo. 2s. $6 d$.}

"Decidedly one of the most careful and valuable of the whole series. When a book is as good as Professor Nichol's, there is little to be said about it, except to recommend it as widely as may be."-Athenaum.

COWPER. By Goldwin Smith. Crown 8vo. 2s. $6 d$.

"Mr. Goldwin Smith has sketched in a few decisive touches the genius of the poet and the weakness of the man."-Daily News.

LOCKE. By Professor Fowler. Crown 8vo. 2s. $6 d$.

"In the case of Locke's biographer, we venture to say that Mr. Morley has been exceptionally fortunate. A pen more competent than Professor Fowler's for this particular work might have been sought, and sought in vain."-Examiner.

WORDSWORTH. By F. W. H. Myers. Crown 8vo. 2s. $6 d$.

" Mr. Myers gives us a picture of the man and an estimate of his work which is certainly not inferior to anything that has preceded it. Possibly the best chapter in the book-every chapter is excellent-is that on Natural Keligion."-Academy.

DRYDEN. By George Saintsbuky. Crown 8vo. 2s. 6 $d$. "It is, beyond question, the best account of Dryden which has yet appeared."-Academly.

\section{IN PREPARATION.}

SWIFT. BY JOHN MORLEY.

A DAM S Mith. By Leonard H. Courtney, M.P.

BENTLEY. By Professor R. C. Jebb.

LANDOR. By Professor Sidney Colvin.

DICKENS. By Professor A. W. WARD.

DE QUINCEY. By Professor Masson.

BERKELEY. By Professor Huxley.

Charles lamb. By Rev. Alfred Ainger.

STERNE. By H. D. TraIll.

Others will follow.

MACMILLAN \& CO., LONDON. 

YB 10081 
